\title{
Psychological Resilience Building in Disaster Risk Reduction: Contributions from Adult Education
}

\author{
Martha Höfler
}

Published online: 30 March 2014

(C) The Author(s) 2014. This article is published with open access at Springerlink.com

\begin{abstract}
This article discusses three questions: What opportunities exist to enhance psychological resilience in adults? Why should psychological resilience promotion be considered an important disaster risk reduction strategy? What contribution can adult education make to such a strategy? Psychological resilience is presented as relational and somewhat malleable, even in adulthood. Although psychological resilience building is often overlooked in social-level disaster risk reduction efforts, it is a key strategy for social resilience building. Questions regarding the extent to which mental resilience can be improved and the techniques with which to do so may be answered by research in the field of adult education. Basic learning and teaching research fundamentals are suggested to create psychological resilience-building strategies in adults.
\end{abstract}

Keywords Adult education - Disaster risk

reduction - Mental health $\cdot$ Psychological

resilience $\cdot$ Resilience building

\section{Introduction}

Preventing mental disorders and promoting mental health are increasingly important issues in the current international discourse of organizations such as the World Health Organization (WHO 2006). Mental health can be understood as the result of mental engagement with the components and structures of an individual's particular social milieu, a complex process influenced by both personal and

\footnotetext{
M. Höfler ( $\square)$
}

Institute of Education and Culture, Chair of Adult Education, Friedrich Schiller University Jena, 07743 Jena, Germany

e-mail: martha.hoefler@uni-jena.de exogenous forces (WHO 2001). There are a variety of risks to healthy psychological functioning that an individual can face, such as the death of or the separation from a loved one, illness or poverty, as well as disaster experiences such as flood or fire; they constitute potential sources of stress and trauma. When taking into consideration the diversity, complexity, and unpredictability of hazards, it is impossible to prevent risk constellations entirely (CSS 2009). This makes each individual's capacity to overcome risks to mental functioning important. The phenomenon of psychological resilience implies such a coping capacity, which leads to positive adjustment and healthy development, even in the face of massive risks (Fingerle 2009).

Serious risks that threaten large populations are considered in disaster risk reduction (DRR), which comprises efforts to protect societies from threats (UNISDR 2009). Resilience building is an increasingly important aspect of DRR and is recognized by international political organizations (DFID 2011; EC 2012; IFRC 2012) as a central goal of support and development efforts in high-risk societies. In DRR, resilience is frequently applied to the coping abilities of social (-ecological) systems such as nations, communities, neighborhoods, and even households (Bahadur et al. 2010; DFID 2011; Australian Government/ Attorney-General's Department 2012; IISD 2013) rather than to the coping capacities of the individuals who make up these systems. However, individuals are not only directly affected by the hazards and disasters that DRR takes into consideration, but are also crucial for the preservation and recovery of social functioning (Masten 2007). This article argues for a more central role of psychological resilience within DRR activities. Questions regarding the extent to which changing mental resilience can be achieved and the techniques with which to do so are answered by educational science. The epistemological interest of 
educational science lies in the purposeful changing of mental processes. Educational science has increased the amount of attention dedicated to the concept of resilience. But research on the psychological coping capacity to overcome risks has historically focused on children and youth (Kluge 2004; Scharnhorst 2010), whereas adult resilience and its promotion have received comparably less attention. However, there is no reason why adult resilience should receive less attention. As DRR seeks to address mental resilience building, the reliance on the basics of educational science may prove beneficial.

This article explores the role of psychological resilience building within DRR efforts in high-risk societies, with a focus on mental resilience building in adults. Adult education is considered with regard to its ability to develop and implement resilience-building measures. The following issues are discussed:

- What opportunities exist to enhance psychological resilience in adults?

- Why should psychological resilience promotion be considered an important DRR strategy?

- What contributions can adult education make to psychological resilience-building strategies?

\section{Recognizing and Promoting Resilience in Adulthood}

Compared to resilience research on children and youth, studies on adult resilience account for only a small proportion of the research (Scharnhorst 2010), and have only been established since the 1980s (Kluge 2004). Because of the various sources of stress an adult person can face in life and due to the possibility to positively influence adult resilience phenomena, exploring adult resilience is highly relevant.

\subsection{Risks as Sources of Mental Stress and Trauma}

A number of diverse risk factors for psychological functioning have been explored, including individual life experiences such as abuse (Moran and Eckenrode 1992), daily stress (Hay and Diehl 2010), and loneliness (Adams et al. 2004). Factors affecting larger groups of people have also been explored, such as social crises and disasters, as, for example, growing up in areas with high rates of poverty and violence (Luthar 1999), or surviving terrorist attacks (Hobfoll et al. 2008). Even natural disasters such as hurricanes (Werner and Smith 1992) and earthquakes (Najarian et al. 2011) have been explored with regard to their negative effect on mental health. Such risks imply healthstraining distress, which can result in psychological dysfunction, leading to mental illness. Reactions to traumatic experiences can result in cognitive and emotional problems such as anxiety, depression, irritability, and loss of intellectual capacity; as well as unhealthy behaviors, such as sleeplessness, social withdrawal, or substance abuse. Psychosomatic reactions, such as increased resting heart rate, can also result from traumatic experiences (Flatten et al. 2011).

\subsection{Coping Capacity in Adulthood and Possible Ways} to Promote It

The phenomenon of psychological resilience suggests a psychological coping capacity in the face of risks. It comprises two dominant aspects (Wustmann 2009; Zautra 2009): the maintenance of a positive health level and the relatively rapid recovery to a positive level of psychological functioning, despite critical or traumatic experiences. Resilience is variable and determined by a number of factors. A person may show resilience at some points in his or her life, but not at others, as was found, for example, in a long-term study by Werner and Smith (1992). Researchers have posited the existence of crucial developmental windows in middle and later life (Schulz and Heckhausen 1996; Ong et al. 2010), which are assumed to be opportunities for enhancing psychological functioning. Little is known about the actual processes that, despite risks, result in a positive psychological functioning level; these processes are sometimes referred to as the black box of resilience research (Luecken and Gress 2010). Although their mechanisms are somewhat mysterious, they are verifiably provided by protective factors. Such factors are the critical starting points for taking resilience-building measures. Resilience is the product of interactions between personal and environmental conditions, and adult resilience research has identified a variety of factors that reduce the probability of dysfunctional adaptive reactions to risk situations and increase positive adaptive reactions. Psychological factors, acquired through learning processes, are seen as being the most decisive in processes of mental resilience (Wustmann 2009; Ong et al. 2010). On a personal level, for example, optimism has been confirmed as a protective factor in adults who experienced traumatic events such as earthquakes (Najarian et al. 2011). Finding purpose in life may also be protective, as was found in atrisk adults who had been exposed to a range of severe traumas such as sexual or physical assault or assault with a weapon (Alim et al. 2008). An internal locus of control and strong self-efficacy were found to be protective in adults who went through a number of risk experiences, such as poverty, hurricanes, or growing up with mentally ill parents (Werner and Smith 1992).

The individual's environment also plays a decisive role in the process of acquiring such protective personal factors. 
On an environmental level, above all, social support has been recognized as a protective factor, helping adults to be resilient in the face of risks such as chronic political violence or natural disasters. This social support can come in a variety of forms, such as parents (Masten et al. 2004), friends (Kiang et al. 2010; Hobfoll et al. 2011), social networks, institutions, and positive role models (Werner and Smith 1992).

In accordance with the different levels at which influencing factors can be located and with individual-based health promotion in general (Wulfhorst 2002), two basic categories of psychological resilience-building approaches can be distinguished: personal-level approaches (that is, promotion of personal factors), and environmental-level approaches (that is, promotion of environmental factors).

A personal-level approach focuses directly on changing actual and potential behavior in a working process with respective individuals, while an environmental-level approach aims to modify the environment of individuals such that adaptive capacity can develop and resilience is possible in adverse situations. Environmental approaches indirectly influence individuals' coping behaviors.

Even if resilience is changeable throughout life, mental resilience promotion efforts are limited in what they can do; not all condition factors of resilience are modifiable. While self-efficacy can be modified during adulthood (Latimer and Ginis 2005), personal protective factors such as temperament remain stable throughout an individual's lifetime (Werner and Smith 1982). In addition, the opportunities to positively influence mental coping capacity rely on program quality, the chances that individuals have to participate, the motivation and skills of recipients, and opportunities for positive coping in the specific situational and environmental context. Human coping capacity has inherent limits and is rare in extreme, chronic risk situations (Masten 2001). Nevertheless, resilience is malleable to some extent. If opportunities for the professional enhancement of mental coping capacity exist, the exploitation of such opportunities seems especially indicated in high-risk populations.

\section{Individual Resilience Building as a Task of Disaster Risk Reduction (DRR)}

While in DRR the resilience concept often is applied to a society's handling of crises and disasters, the role of an individual's coping capacity in the face of such stressors is in question.

\subsection{The Role of Psychological Resilience in DRR}

DRR implies a mandate; it refers to the exploration and implementation of measures to prevent risk constellations or to lessen their effects and support functioning and resilience (UNISDR 2009). Resilience interpretations by DRR see this phenomenon as "the ability of a system, community or society exposed to hazards to resist, absorb, accommodate to and recover from the effects of a hazard in a timely and efficient manner" (UNISDR 2009, p. 24). In the case of disasters that are seen as overwhelming a specific society's ability to cope, disaster resilience is of interest, which is seen as the ability of social (-ecological) systems to manage changes caused by disaster events such as earthquakes, drought, or violent conflict, thereby avoiding long-term negative consequences (DFID 2011).

In DRR practices that can be implemented before, during, or after disasters (Twigg 2004), community-based resilience-building efforts predominate in comparison to individual-based measures. Community-based approaches that build capacity on the family, local, and national levels have been used, for example, in strategies of preparedness for a variety of hazards by organizations such as Palang Merah Indonesia and the Canadian Red Cross in Aceh Province and on Nias Island (Kafle 2010); in disaster preparedness activities by the International Federation of Red Cross and Red Crescent Societies in Asia, Africa, and Latin America (IFRC 2008); in poverty-reduction strategies by the United Nations Development Programme in Sudan's River Nile State (UNDP 2013); in local risk management in Navua, Fiji by the National Disaster Management Office; as well as in climate change and food security initiatives in Samoa by Women in Business for Development Inc (Gero et al. 2011). In such strategies the focus is on the enhancement of community capacities such as new agriculture practices, communication structures, institutional capacities, and funding channels.

The particular importance of resilience building on the broader community level versus doing so on an individual level is highlighted, for instance, by the Institute of Development Studies (Bahadur et al. 2010). In DRR, resilience building on an individual level has received comparably less attention. Individual resilience is sometimes mentioned as an aim within community resiliencebuilding strategies IFRC 2012), and in practice some individual resilience-building measures exist that focus on mental resilience strengthening. These measures can be interpreted as part of overall DRR practice. Examples include the IRISS program that works in areas with high rates of HIV infection to strengthen individuals' coping with HIV diagnosis (Moskowitz 2010), or the Mongolian Red Cross Project that gives social support to people with disrupted traditional networks in the face of disasters (BRC 2013). However, when individual coping ability is mentioned in DRR, the focus is more often on the ability to physically survive acute crises and disaster situations, rather than on the stress regulation and stress management 
capacities that are also essential to effectively dealing with threats. This is evident when, for instance, individual coping capacity is linked to knowledge of traditional droughtresistant seed varieties that can be eaten at times of food scarcity (Twigg 2004), or when individual resilience strengthening is seen in terms of delivering vaccinations on the individual level (IFRC 2012). This reductive thinking about the nature of individual coping ability exemplifies the criticism that has been raised against how risk analysis, a key step in developing and implementing DRR measures, is conducted. In such analyses the focus is primarily on the more visible and quantifiable elements at risk, such as buildings, physical or financial assets, and human lives, as opposed to on human vulnerabilities and capacities (Twigg 2004). If DRR addresses psychological capacity building at all, in most cases it seems to do so indirectly, as a byproduct of community resilience building. For example, in cyclone risk-reduction efforts, the Bangladesh Red Crescent sees the building of individual self-efficacy as one of the desirable consequences of community capacity promotion (Schmuck 2002). In his comprehensive DRR best practice review, Twigg noted that psychological resilience is especially overlooked in the discourse on post-disaster recovery (Twigg 2004); this is true despite the fact that the psychological impact of disasters and the resulting stress is much debated (Norris et al. 2002; Bonanno et al. 2006) and that stress-related disorders are recognized as relevant target areas for post-disaster intervention (Norris et al. 2008).

\subsection{Reasons for the Establishment of Stronger \\ Psychological Resilience-Building Interventions}

Despite the view of the particular importance of resilience building on the broader community level versus doing so on an individual level, this article argues that more research needs to be done focusing on psychological resilience building, and that this area needs to be considered an essential action strategy within DRR efforts. Even if community-based resilience building on social levels such as households, local areas, and nations can contribute to psychological resilience-for example, through creating a secure and supportive environment for the individual, which has been confirmed to serve as a protective mental health function (see Sect. 2.2) - not all aspects of social functioning and resilience, such as economic and physical resources, information, and communication structures contribute in the same way to psychological resilience. These factors can be protective on an environmental level for at-risk individuals, but are not necessarily so. Resilience building in social systems and on the individual level are not interchangeable, as psychological and social systems are fundamentally different. Therefore, community-based approaches may not be able to integrate the nurturing of individual psychological resilience-building and its conditions systematically if they do not focus directly on the needs and potentials of the individual psyche in the face of crises situations.

A justification for a stronger establishment of a mental resilience perspective in DRR practice is given through the gaze of DRR that is directed towards populations that are exposed to multiple stressors, and that are therefore most intensively challenged and overwhelmed by their circumstances. Furthermore, in high risk areas, such as developing countries, where care-related infrastructure and mental health support often are lacking, external interventions are necessary. Integrating psychological resilience building into DRR strategies not only has positive consequences for individuals, but bolstering personal strength is crucial for social communities. In DRR, human abilities are recognized as being key factors in the protection, reconstruction, and development of communities, such as the abilities to practice social roles, to competently participate in and support a community, and to take responsibility for risks (Twigg 2004; Australian Government/Attorney-General's Department 2012). However, mental health despite existing risks (that is, psychological resilience) is an essential prerequisite for such competencies. Accordingly, the World Disasters Report 2004 named health as a protective factor for social resilience (IFRC 2004). The United Nations International Strategy for Disaster Reduction (UNISDR 2009) further noted that psychological dysfunction is a possible hazard for social resilience. If the individual cannot cope successfully, he or she cannot be mentally resilient against hazards; in this case, the manifestation of symptoms of psychological dysfunction, such as diseases, social disengagement, and criminal activity are likely (Werner and Smith 1992). Such behaviors burden the social system, for instance, due to the need for more criminal justice facilities, or due to an increased need for health and social services. The promotion of individual resilience can therefore reduce the strain on social systems. This can lessen the impact of later disasters, as the ultimate extent of a disaster is crucially determined by the reaction of the affected population. Japan's response to the 2011 tsunami is an example of a particularly positive and effective reaction to a disaster. After experiencing a massive earthquake, a tsunami, and a catastrophic nuclear accident, social order was quickly restored. This was not only ascribed to well-trained and dedicated non-profit organizations (Parashar et al. 2011), but also due to the local population's cultural socialization in key traits such as calmness and patience (Bara 2011). The abilities to network effectively and to maintain close neighborly bonds (Parashar et al. 2011) also may have been protective for both individuals and the larger society in this instance.

Psychological resilience building as a DRR strategy is not only relevant for high-risk populations but also for 
professionals working in particularly stressful areas and situations. Flatten and colleagues (2003) reported that rescue workers routinely work under stressful conditions, even in their everyday work, not just in notable, large-scale rescue operations such as the 1998 train accident in Eschede. Rescuers consider themselves to be a high-risk group (Krüsmann et al. 2007) because their job requires them to work in stressful situations on a daily basis. This stress can compromise a rescuer's mental health, which can lead to the negative individual and social consequences discussed above. Rescuers can also experience impaired decision-making ability or impaired efficiency, which can have fatal consequences in an emergency situation.

In summary, DRR's goal of strengthening community resilience cannot ignore the importance of individual psychological resilience. Mental resilience is essential for social functioning, and individual-based resilience building can be a beneficial part of community-oriented resilience approaches. Many DRR action projects are criticized as coming to an end too quickly and suddenly (Twigg 2004), making sustainable development an important issue within this field. Building psychological coping capacity takes time; efforts must go beyond psychological first aid during or immediately after disasters, extending into a developmental strategy that promotes environmental and personal strength, enhancing coping capacity, and protecting mental health in the face of risks and stressors.

\section{Adult Education's Contribution to Psychological Resilience-Building Strategies}

To date, little research has been conducted on interventions to promote resilience-and particularly in adults (Burton et al. 2010). Despite some existence of validated resiliencebuilding measures like the Promotion Adult Resilience Program (Liossis et al. 2009), a theoretical discussion on adult resilience training, based on the resilience concept, is lacking. However, as adult education's main aim is the purposeful change of mental processes, this field has a great deal of research and methods that could be beneficial in developing and implementing adult resilience-building measures in DRR. Basic areas of adult-educational research can inform both personal- and environmental-level resilience-building approaches. Central questions in resilience promotion that focuses on personal condition factors and thus on directly changing coping behavior in adults are:

(1) What are special features of age-specific coping behavior?

(2) Which protective psychological factors have been identified as flexible and can therefore be changed throughout the lifespan of an individual?
(3) What methods, actions, and settings are most suitable for different at-risk target groups?

(4) What skills must professionals have to impact adult mental processes through behavioral-pedagogical work?

These are all questions related to learning in adulthood, matching the adult education research focus on learning, teaching, and instruction. Adult education explores specific aspects of learning in certain target groups. As resilience has been shown to be a phenomenon based strongly on learning processes, adult education holds beneficial foundational knowledge to understanding individual coping capacities. This application of research findings integrates age-specific knowledge (Yang et al. 2006; Baltes et al. 2010), knowledge on multiple learning styles and learning disabilities (Goldstein 2006), insights into individualized and biography-oriented learning (Dominice 2000; Alheit and Dausin 2006; Nittel 2013), personality development through learning (Mezirow 1995; Ebner et al. 2006), and characteristics of learning in and through mental crises, especially those relevant to DRR, such as natural disasters, terrorist attacks, persecution, or imprisonment (Schuchard 2006; Nittel 2011).

Through its primary focus on didactics, adult education can deliver tools to support learning in the areas mentioned above. They can be applied to effectively promote healthy coping behavior, making use of findings on appropriate forms of learning and educational settings for at-risk individuals, such as counseling or group interventions, as well as through the respective suitable teaching methodologies. Furthermore, adult education has conducted basic research into the special skills held by professionals who work effectively with adults (Buiskool et al. 2010), such as good communication skills. The DRR action field of risk communication is one field where such knowledge could be applied (Eisenman et al. 2007; Australian Government/ Attorney-General's Department 2012; CDC 2013). As individual actions mitigating against or preparing for disasters are based on individual risk perceptions (Mishra et al. 2011) and make a strong impact on how much stress individuals experience in threatening situations, professionally informed risk communication to individuals can positively influence coping capacity, give sufficient knowledge of what to do in the event of a disaster, and prevent mental overload. Central questions in resilience promotion that focuses on environmental condition factors and thus on indirectly influencing coping behavior in adults are:

(1) How can environments be manipulated to facilitate the development of strong and healthy coping behaviors in at-risk populations?

(2) How can institutional structures of mental health support be created in high-risk areas to foster individual resilience? 
(3) How can the professions that contribute to the protection and development of secure environments and reduced risk be nurtured and expanded?

(4) How can a culture be created in which risks, crises, and disasters are handled positively?

Adult education can make a contribution to resolving such questions, for example, through research in areas such as life-world-, setting-, and milieu-based approaches (Hiemstra 1991; Barz and Tippelt 2010), designing environments for individuals at risk that encourage development. Such approaches are adapted to groups of people living in specific environments, including people in adverse environments, and can focus on the specific needs and relevant support structures. Such approaches have a special individual-oriented focus that community-based DRR interventions have not necessarily had. Another aspect of adult education is vocational training (Sauter 2008), which could contribute to the education of mental health professionals as well as professional helpers in DRR, enhancing safety and support for community members who are facing hazards and disasters. Training could be organized for both professionals and volunteers, including essential refresher courses (Twigg 2004). This training would not only be beneficial to the mental protection and preparedness of the professionals themselves, but would reduce the likelihood of mental overburdening for community members in crises situations.

Adult education research also offers insights into cultural learning processes (de Groote and Nebauer 2008; Theile 2008), which can contribute to cultural rebuilding following social crises and disasters. Cultural recovery following a disaster implies more than just compensation for damages, material reconstruction, and the adaption to technical requirements, such as the development of early detection systems. Disasters can influence collective memory (BPB 2013) and make cultural processing and integration of what happened potentially necessary. This might take the form of building monuments or memorials, as well as civic-educational initiatives (Fechler et al. 2000). Such cultural learning actions can be supported by adult education, creating an environment for an individual that offers opportunities to discuss and handle crises.

Multidisciplinary collaboration is required in DRR practice (Twigg 2004). Adult education could offer a great deal of beneficial basic research, which DRR could use in psychological resilience-building interventions.

\section{Conclusion}

This article shows that psychological resilience is a relational and dynamic phenomenon, which is somewhat malleable, even later in life. Although there may be limits in how much the coping capacity of high-risk populations can be enhanced, adult resilience can be supported by promoting confirmed protective factors through personal-level and environmentallevel approaches. The current state of DRR practice shows little attention to psychological resilience building. The knowledge of the needs of individuals in high-risk areas, as well as the accepted benefits of psychological resilience for both individual and community functioning means that establishing psychological resilience-building strategies seems promising. This can be accomplished within a range of basic areas of adult education research such as life-world-, setting- and milieu-based approaches, age-related learning and personality development, learning in and through crises and teaching methods. These are promising ways in which adult education can contribute to professional mental resilience-building strategies.

Open Access This article is distributed under the terms of the Creative Commons Attribution License which permits any use, distribution, and reproduction in any medium, provided the original author(s) and the source are credited.

\section{References}

Adams, K., S. Sanders, and E. Auth. 2004. Loneliness and depression in independent living retirement communities: Risk and resilience factors. Aging and Mental Health 8(6): 475-485.

Alheit, P., and B. Dausin. 2006. Biographical research in adult education (Biographieforschung in der Erwachsenenbildung). In Handbuch erziehungswissenschaftliche Biographieforschung, ed. H.-H. Krüger, and W. Marotzki, 431-457. Wiesbaden: VS Verlag (in German).

Alim, T., A. Feder, R. Graves, Y. Wang, J. Weaver, M. Westphal, J. Doucette, T. Mellman, et al. 2008. Trauma, resilience and recovery in a high-risk African-American population. American Journal of Psychiatry 165(12): 1566-1575.

Australian Government/Attorney-General's Department. 2012. National strategy for disaster resilience. http://www.ag.gov.au/ EmergencyManagement/Documents/NationalStrategyforDisaster Resilience-CompanionBooklet.PDF.

Bahadur, A.V., M. Ibrahim, and T. Tanner. 2010. The resilience renaissance? Unpacking of resilience for tackling climate change and disasters. Institute of Developmental Studies. http://commu nity.eldis.org/.59e0d267/resilience-renaissance.pdf.

Baltes, P.B., K. Mayer, H. Helmchen, and E. Steinhagen-Thiessen. 2010. The Berlin aging study (BASE). Overview and introduction (Die Berliner Altersstudie (BASE): Ueberblick und Einfuehrung). In Die Berliner Altersstudie, ed. U. Lindenberger, J. Smith, K. Mayer, and P. Baltes, 25-58. Berlin: Akademie-Verlag (in German).

Bara, C. 2011. Resilience and vulnerability in Switzerland: The storm disaster of 2005. (Resilienz und Vulnerabilitaet in der Schweiz: Die Unwetter-Katastrophe von 2005). In Bulletin 2011 zur schweizerischen Sicherheitspolitik, ed. D. Trachsler, and A. Wenger, 77-105. Zurich: Center for Security Studies (CSS) (in German).

Barz, H., and R. Tippelt. 2010. Life world, life situation, lifestyle and adult education (Lebenswelt, Lebenslage, Lebensstil und Erwachsenenbildung). In Handbuch der Erwachsenenbildung, 4th 
edn., ed. R. Tippelt, and A. von Hippel, 117-136. Wiesbaden: VS Verlag (in German).

Bonanno, G., S. Galea, A. Bucciarelli, and D. Vlahov. 2006. New York City in the aftermath of the september 11th terrorist attack. Psychological Science 17(3): 181-186.

BPB (Bundeszentrale für politische Bildung). 2013. Unfinished business: The Algerian war in France's collective memory (Ein unvollendeter Aufarbeitungsprozess: Der Algerienkrieg im kollektiven Gedächtnis Frankreichs). http://www.bpb.de/interna tionales/europa/frankreich/152531/algerienkrieg (in German).

BRC (British Red Cross). 2013. Social care in Mongolia. http://www. redcross.org.uk/What-we-do/Health-and-social-care/Socialsupport-overseas/Social-care-in-Mongolia.

Buiskool, B., S. Broek, J. van Lakerveld, G. Zarifis, and M. Osborne. 2010. Key competences for adult learning professionalscontribution to the development of a reference framework of key competences for adult learning professionals. http://www.ec. europa.eu/education/more-information/doc/2010/keycomp.pdf.

Burton, N., K. Pakenham, and W. Brown. 2010. Feasibility and effectiveness of psychosocial resilience training: A pilot study of the READY program. Psychological Health Medicine 15(3): 266-277.

CDC (Center for Disease Control and Prevention). 2013. Crisis \& emergency risk communication (CERC). http://emergency.cdc. gov/cerc/.

CSS (Center for Security Studies). 2009. Resilience: A concept for crisis and catastrophe management (Resilienz: Konzept zur Krisen- und Katastrophenbewaeltigung). CSS Analysen zur Sicherheitspolitik 60 (Zurich). http://www.css.ethz.ch/publica tions/DetailansichtPubDB?rec_id=655 (in German).

de Groote, K., and F. Nebauer (eds.). 2008. Cultural education in old age. An inventory of cultural learning opportunities for seniors in Germany (Kulturelle Bildung im Alter. Eine Bestandsaufnahme kultureller Bildungsangebote für Ältere in Deutschland). Munich: Kopaed (in German).

DFID (Department for International Development). 2011. Saving lives, preventing suffering and building resilience. https://www. gov.uk/government/uploads/system/uploads/attachment_data/ file/67468/The_20UK_20Government_s_20Humanitarian_20Pol icy_20_20September_202011_20-_20Final.pdf.

Dominice, P. 2000. Learning from our lives. Using educational biographies with adults. San Francisco: Jossey-Bass.

Ebner, N., A. Freund, and P. Baltes. 2006. Developmental changes in personal goal orientation from young to late adulthood: From striving for gains to maintenance and prevention of losses. Psychology and Aging 21(4): 664-678.

EC (European Commission). 2012. The EU approach to resilience: Learning from food security crises. Communication from the Commission to the European Parliament and Council, Oct 3, 2012. http://ec.europa.eu/europeaid/what/food-security/documents/ 20121003-comm_en.pdf.

Eisenman, D., K. Cordasco, S. Asch, J. Golden, and D. Glik. 2007. Disaster planning and risk communication with vulnerable communities: Lessons from Hurricane Katrina. American Journal of Public Health 97(1): 109-115.

Fechler, B., G. Kößler, and T. Lieberz-Groß (eds.). 2000. Education after Auschwitz in the multicultural society. Educational and sociological approaches (Erziehung nach Auschwitz in der multikulturellen Gesellschaft. Pädagogische und soziologische Annaeherungen). Weinheim: Max Traeger Stiftung (in German).

Fingerle, M. 2009. Current state of research regarding the resilience concept (Aktueller Forschungsstand zum Resilienzkonzept). Jugendhilfe 47(3): 204-208. (in German).

Flatten, G., O. Bär, K. Becker, J. Bengel, U. Frommberger, A. Hofmann, W. Lempa, and A. Möllering. 2011. S2-Diagnostics and treatment of acute consequences of mental trauma (S2-
Diagnostik und Behandlung von akuten Folgen psychischer Traumatisierung). Trauma und Gewalt 3: 214-221. (in German).

Flatten, G., K. Seiger, R. Rossaint, and E. Petzold. 2003. The helpless helper. Dealing with traumatic stress in emergency response ("Der hilflose Helfer". Zum Umgang mit traumatischen Belastungen im Rettungsdienst). Notfall \& Rettungsmedizin 6(4): 265-270 (in German).

Gero, A., K. M'eheux, and D. Dominey-Howes. 2011. Integrating community based disaster risk reduction and climate change adaptation: Examples from the Pacific. Natural Hazards and Earth System Sciences 11: 101-113.

Goldstein, S. 2006. Emotional problems in adults with learning disabilities. http://www.ldaamerica.org/aboutld/professionals/ emotional.asp.

Hay, E., and M. Diehl. 2010. Reactivity to daily stressors in adulthood: The importance of stressor type in characterizing risk factors. Psychology and Aging 25(1): 118-131.

Hiemstra, R. (ed.). 1991. Creating environments for effective adult learning. New directions for adult and continuing education. San Francisco: Jossey-Bass.

Hobfoll, S., D. Canetti-Nisim, R. Johnson, P. Palmieri, J. Varley, and S. Galea. 2008. The association of exposure, risk and resiliency factors with PTSD among Jews and Arabs exposed to repeated acts of terrorism in Israel. Journal of Traumatic Stress 21(1): 9-21.

Hobfoll, S., A. Mancini, B. Hall, D. Canetti, and G. Bonanno. 2011. The limits of resilience: Distress following chronic political violence among Palestinians. Social Science and Medicine 72(8): $1400-1408$.

IFRC (International Federation of Red Cross and Red Crescent Societies). 2004. World disasters report: Focus on community resilience. http://www.redcross.int/EN/mag/magazine2004_2/ book.html.

IFRC (International Federation of Red Cross and Red Crescent Societies). 2008. A framework for community safety and resilience. In the face of disaster risk. http://www.ifrc.org/Global/ Case\%20studies/Disasters/cs-framework-community-en.pdf.

IFRC (International Federation of Red Cross and Red Crescent Societies). 2012. The road to resilience. Bridging relief and development for a more sustainable future. IFRC discussion paper on resilience-June 2012. http://www.ifrc.org/PageFiles/96178/ 1224500-Road\%20to\%20resilience-EN-LowRes\%20(2).pdf.

IISD (International Institute for Sustainable Development). 2013. Disaster resilience. http://www.iisd.org/ecp/es/resilience/.

Kafle, S. 2010. Integrated community based risk reduction: An approach to building disaster resilient communities. Canadian Red Cross, Indonesia Delegation. http://www.preventionweb. net/files/14348_14348SheshKafleICBRR2010.pdf.

Kiang, L., J. Grzywacz, A. Marin, T. Arcury, and S. Quandt. 2010. Mental health in immigrants from nontraditional receiving sites. Cultural Diversity and Ethnic Minority Psychology 16(3): 386-394.

Kluge, A. 2004. Resilience research: Current research status (Resilienzforschung: Aktueller Forschungsstand). EU-Projekt: Arbeitsfaehigkeit erhalten (AEIOU). http://www.equalaeiou.at/.../ Resilienz_TeilI_Darstellung_Dez_2004.pdf (in German).

Krüsmann, M., R. Karl, M. Hagl, and W. Butollo. 2007. Prevention in the first response sector-The significance of training, follow-up care and psychotherapy (Praevention im Einsatzwesen - zum Stellenwert von Schulungen, Nachsorge und Psychotherapie). Psychotherapie 12: 326-335. (in German).

Latimer, A., and K. Ginis. 2005. Change in self-efficacy following a single strength training session predicts sedentary older adults' subsequent motivation to join a strength training program. American Journal of Health Promotion 20(2): 135-138.

Liossis, P., I. Shochet, P.M. Millear, and H. Biggs. 2009. The promoting adult resilience (PAR) program: The effectiveness of 
the second, shorter pilot of a workplace prevention program. Behaviour Change 26(2): 97-112.

Luecken, L., and J. Gress. 2010. Early adversity and resilience in emerging adulthood. In Handbook of adult resilience, ed. J. Reich, A. Zautra, and J. Hall, 238-257. New York: Guilford Press.

Luthar, S. 1999. Poverty and children's adjustment. Thousand Oaks, CA: Sage.

Masten, A. 2001. Resilience in development: Everyday miracles (Resilienz in der Entwicklung: Wunder des Alltags). In Entwicklung und Risiko. Perspektiven einer Klinischen Entwicklungspsychologie, ed. G. Roeper, C. von Hagen, and G. Noam, 192-219. Stuttgart: Kohlhammer (in German).

Masten, A. 2007. Resilience in developing systems: Progress and promise as the fourth wave rises. Development and Psychopathology 19(3): 921-939.

Masten, A., K. Burt, G. Roisman, J. Obradović, D. Jeffrey, and A. Tellegen. 2004. Resources and resilience in the transition to adulthood: Continuity and change. Developmental Psychopathology 16(4): 1071-1094.

Mezirow, J. 1995. Transformation theory of adult learning. In Defense of the lifeworld, ed. M. Welton, 39-70. New York: SUNY Press.

Mishra, S., D. Suar, and D. Paton. 2011. Self-esteem and sense of mastery influencing disaster preparedness behavior. Australasian Journal of Disaster and Trauma Studies. http://trauma.massey. ac.nz/issues/2011-1/mishra.htm.

Moran, P., and J. Eckenrode. 1992. Protective personality characteristics among adolescent victims of maltreatment. Child Abuse and Neglect 16(5): 743-754.

Moskowitz, J. 2010. Positive affect at the onset of chronic illness. Planting the seeds of resilience. In Handbook of adult resilience, ed. J. Reich, A. Zautra, and J. Hall, 465-483. New York: Guilford Press.

Najarian, L., S. Sunday, V. Labruna, and I. Barry. 2011. Twenty-year follow-up of adults traumatized during childhood in Armenia. Journal of Affective Disorders 135(1-3): 51-55.

Nittel, D. 2011. The appropriation of disease: Processing biographical crises in the mode of learning (Die Aneignung von Krankheit: Bearbeitung lebensgeschichtlicher Krisen im Modus des Lernens). Der pädagogische Blick. Zeitschrift für Wissenschaft und Praxis in pädagogischen Berufen 2: 80-90. (in German).

Nittel, D. 2013. Procedural learning dimensions: A biographyanalytical instrument for observation of educational processes in people with life-threatening illness and in support of educational interventions (Prozessuale Lerndimensionen: Ein biographieanalytisches Instrument zur Beobachtung von Bildungsprozessen bei Menschen mit lebensbedrohlicher Erkrankung und zur Begründung pädagogischer Interventionen). In Der soziale Körper. Interdisziplinäre Zugänge zur Leiblichkeit, ed. H. Herzberg, and A. Seltrecht, 107-153. Opladen: Barbara Budrich Verlag (in German).

Norris, F., M. Friedman, and P. Watson. 2002. 60,000 disaster victims speak: Part I. An empirical review of the empirical literature, 1981-2001. Psychiatry 65(3): 207-239.

Norris, F., S. Stevens, B. Pfefferbaum, K. Wyche, and R. Pfefferbaum. 2008. Community resilience as a metaphor, theory, set of capacities, and strategy for disaster readiness. American Journal of Community Psychology 41(1-2): 127-150.

Ong, A., C. Bergeman, and S.-M. Chow. 2010. Positive emotions as a basic building block in adult resilience. In Handbook of adult resilience, ed. J. Reich, A. Zautra, and J. Hall, 81-93. New York: Guilford Press.

Parashar, S., N. Uy, F. Glenn, H. Nguyen, F. Mulyasari, J. Joerin, and R. Shaw. 2011. Mega disaster in a resilient society: The great east Japan (Tohoku Kanto) earthquake and tsunami of 11th March 2011. Synthesis and initial observations, international environment and disaster management. Kyoto: Graduate School of Global Environmental Studies, Kyoto University.

Sauter, E. 2008. Vocational training (Berufliche Weiterbildung). In Ausbilder-Handbuch. Loseblattwerk, ed. G. Cramer, H. Schmidt, and W. Wittwer. http://www.wb-erwachsenenbildung.de/onlinewoerterbuch/?tx_buhutbedulexicon_main[entry] $=20 \& t \mathrm{tx}_{-}$ buhutbedulexicon_main[action]=show\&tx_buhutbedulexicon_ main $[$ controller] $=$ Lexicon\&cHash $=05695 \mathrm{e} 08 \mathrm{~b} 05 \mathrm{bae} 481 \mathrm{da} 1 \mathrm{c} 6 \mathrm{~b}$ $644 \mathrm{f} 6 \mathrm{~cd} 8 \mathrm{c}$ (in German).

Scharnhorst, J. 2010. Individual power of resilience-a necessary core competence? Resilience research in theory and practice (Individuelle Widerstandskraft - eine notwendige Kernkompetenz? Resilienzforschung in Theorie und Praxis). Personalfuehrung 34(37): 34-41. (in German).

Schmuck, H. 2002. Empowering women in Bangladesh. Asia Pacific FOCUS. International Federation of Red Cross and Red Crescent Societies (IFRC). http://reliefweb.int/report/bangladesh/empow ering-women-bangladesh.

Schuchard, E. 2006. Why me? Learning to live in crises. The result of a study of live stories covering a century. Geneva: Bertelsmann.

Schulz, R., and J. Heckhausen. 1996. A life span model of successful aging. American Psychologist 51(7): 702-714.

Theile, E. 2008. Culture of remembrance and adult education (Erinnerungskultur und Erwachsenenbildung). Schwalbach: Wochenschau-Verlag. (in German).

Twigg, J. 2004. Disaster risk reduction: Mitigation and preparedness in development and emergency programming. Good practice review 9. London: Humanitarian Practice Network, Overseas Development Institute.

UNDP (United Nations Development Programme). 2013. Fast facts: Poverty reduction. http://www.undp.org/content/undp/en/home/ librarypage/results/fast_facts/poverty-reduction/.

UNISDR (United Nations International Strategy of Disaster Reduction). 2009. 2009 UNISDR terminology on disaster risk reduction. http://www.unisdr.org/we/inform/terminology.

Werner, E., and R. Smith. 1982. Vulnerable, but invincible. A longitudinal study of resilient children and youth. New York: McGraw-Hill.

Werner, E., and R. Smith. 1992. Overcoming the odd. High-risk children from birth to adulthood. Ithaca: Cornell University Press.

WHO (World Health Organization). 2001. World Health Report 2000. Mental health: New understanding, new hope. http://www.who. int/whr/2001/en/.

WHO (World Health Organization). 2006. Mental health: Accepting challenges, creating solutions. Report on the conference of ministers of the European region of the WHO (Psychische Gesundheit: Herausforderungen annehmen, Loesungen schaffen. Bericht ueber die Ministerkonferenz der Europaeischen Region der WHO). Kopenhagen: Weltgesundheitsorganisation, Regionalbuero fuer Europa (in German).

Wulfhorst, B. 2002. Theory of health education. Justification, task and function of health education (Theorie der Gesundheitspädagog$i k$. Legitimation, Aufgabe und Funktion von Gesundheitserziehung). Munich: Juventa (in German).

Wustmann, C. 2009. Resilience. Promoting resilience of children in day-care facilities. Contributions to the quality of education (Resilienz. Widerstandsfaehigkeit von Kindern in Tageseinrichtungen foerdern. Beitraege zur Bildungsqualitaet), 2nd edn. Düsseldorf: Cornelsen (in German).

Yang, L., R. Krampe, and P. Baltes. 2006. Basic forms of cognitive plasticity extended into the oldest-old: Retest learning, age, and cognitive functioning. Psychology and Aging 21(2): 372-378.

Zautra, A. 2009. Resilience: One part recovery, two parts sustainability. Journal of Personality 77(6): 1935-1943. 